Since claims for future rent were not provable before the amendment, they were not discharged. Bankruptcy, of itself, did not terminate the lease, and the lessee was still liable for rent. ${ }^{16}$ The amendment in allowing partial proof of rent claims raises a question as to the extent of discharge: is the claim discharged in full or only to the extent provable? Discharge in full may not seem very objectionable where bankruptcy, by virtue of a stipulation, terminates or allows the lessor to terminate the lease, but if the lease is not terminated by bankruptcy and the effect of partial provability is to discharge the lessee from all obligation for future rent, the lessee will have the entire term, even though the landlord can prove for only one year's rent. This consideration may lead to the conclusion that the bankrupt is discharged as to rent claims only to the extent that they are provable. Another solution, perhaps, is to construe the amendment as changing the rule that bankruptcy, of itself, does not terminate the lease. ${ }^{\mathrm{7}} \S 77 \mathrm{~b}(\mathrm{~b})$ of the Bankruptcy Act, ${ }^{18}$ regulating provability of landlords' claims in corporate reorganizations, raises a parallel problem.99

\title{
DELEGATION OF LEGISLATIVE POWERS TO THE EXECUTIVE-THE NIRA OIL CASE
}

A recent decision exciting much comment was that in the NIRA Oil Case, Panama Refining Co. v. Ryan, dealing with the power of Congress to delegate legislative functions to the executive. ${ }^{2}$ The case marks the first time such a delegation has been held invalid by the Supreme Court. ${ }^{3}$ It is noteworthy that,

${ }^{16}$ Schneck v. Lewis, I2x Misc. 370, 201 N.Y.S. 282 (I923); Metropolitan Life Ins. Co. v. Levinsky, I53 Misc. 204, 274 N.Y.S. 577 (I934). One reason given at an early date for the rule that claims for future rent were not provable in bankruptcy was that bankruptcy terminated the lease. In re Jefferson, 93 Fed. 948 (D.C. Ky. 1899 ); In re J. Sapinsky \& Sons, 206 Fed. 523 (D.C.Ky. $x_{9} \mathrm{r}_{3}$ ); Patterson, Does the Relation of Landlord and Tenant Become Severed by Operation of the Bankrupt Law?, 39 Am. L. Reg. 656 (I900). This was soon repudiated. In re Ells, 98 Fed. 967 (D.C.Mass. rgoo); In re Roth \& Appel, I8r Fed. 667 (C.C.A. 2d I9Io); In re Sherwoods, Inc., 2ro Fed. 754 (C.C.A. 2d Igr3); In re Mlle. Lemaud, r4 F. (2d) 208 (D.C. Mass. I925); Kessler v. Slappey, 34 Ga. App. 6I4, I30 S.E. 92I (I925).

${ }_{7} 2$ Remington, Bankruptcy (r935 Supp.), § 793.

${ }^{28} 48$ Stat. 9 I2 (I934), II U.S.C.A. \$ 207 (I934 Supp.).

19 Brady, Satisfaction of Dissenting Claims in Reorganization Schemes under $\S 77^{B}$, I9 Marq. I. Rev. 106 (1935).

${ }^{I} 55$ Sup. Ct. 24 I (I935), reversing 7 I F. (2d) I (C.C.A. 5th I934), reversing 5 F. Supp. 633 (E.D. Tex. I934).

${ }^{2}$ See 48 Harv. I. Rev. 798 (I935). This note considers both the delegation problem and a second point of the case, namely, the holding that the executive order issued in compliance with the terms of the NIRA was a violation of due process of law for failure to state any findings on which the order was based. This latter holding establishes a new rule of law.

3 Black, The National Recovery Act and the Delegation of Legislative Power to the President, ig Corn. L.Q. 389,392 (r934). 
of the so-called liberals on the Supreme Court, only Mr. Justice Cardozo dissented. 4

The oil decision has started anew a consideration of the much discussed "delegation of powers" doctrine. This doctrine has been traced back, through Kent's Commentaries and Coke, to a mistranslation of Bracton's text. 5 Locke and English political experience may have contributed to its growth. ${ }^{6} \mathrm{It}$ and the "separation of powers" doctrine 7 are treated as implied from the separate grants of power to each of the three departments of government in the first three articles of the Constitution. All that Bracton's text, Locke's observations, and the terms of the Constitution obviously mean is that such a body as Congress cannot irrevocably delegate its powers. The limitation has, of course, developed more serious implications in the decisions of state courts. Regardless of the source of the doctrine and the manner in which it became a part of our law, the Supreme Court in a long line of cases recognized the dogma in terms, but had not applied it in any instance before the Panama Oil case. ${ }^{8}$

Probably the earliest American case said to involve the doctrine is The Brig Aurora, ${ }^{9}$ which was cited with approval in the leading case of Field v. Clark. ${ }^{10}$

4In the more recent "gold clause" decision, which has excited public opinion as a "policy" holding on the validity of the New Deal legislation, the four Supreme Court "liberals," Chief Justice Fughes, and Justices Brandeis, Stone, and Roberts, joined with Justice Cardozo in upholding the legislation. Norman v. B. \& O. R. Co., 55 Sup. Ct. 407 (I935); Nortz v. U.S. 55 Sup. Ct. 428 (I935); Perry v. U.S., 55 Sup. Ct. 432 (I935). It seems strange that in the NIRA case the court disregarded an unusually strong line of liberal precedents in holding the delegation unconstitutional.

5 Duff and Whiteside, Delegata Potestas Non Potest Delegari: A Maxim of American Constitutional Law, I4 Corn. L.Q. I68 (I929).

${ }^{6}$ See Locke, Of Civil Government (Everyman ed. I924) Bk. II, c. XI, § I4I; c. XIV, § I59. Unsuccessful attempts have been made to extend the maxim in question to the powers of corporate directors. Such extension, if accepted, would undoubtedly greatly restrict business transactions. See Hoyt v. Thompson's Executors, I9 N.Y. 207 (1859).

7 This note does not purport to deal with the wider field of separation of powers. For an account of the development of that doctrine, see Sharp, The Classical American Doctrine of "The Separation of Powers," 2 Univ. Ch. L. Rev. 385 (I935).

${ }^{8}$ Supra note 5, at I94.

${ }_{7}$ Cranch (U.S.) 382 (I813). The question here was whether Congress could make the revival of the non-intercourse acts of 1809 depend on the subsequent proclamation of the President that Great Britain and France had not revoked or modified certain edicts so that they ceased to violate neutral rights. It was held that the legislature might exercise its discretion conditionally in this manner. The delegation doctrine was not discussed, nor was it necessary to discuss it. See Duff and Whiteside, sicpre note 5 at I76.

ro $x_{43}$ U.S. 649 (1892). Here the court upheld the "flexible" provisions of the McKinley tariff, which allowed the President to reduce the revenue and equalize duties on imports and to suspend by proclamation the free introduction of certain articles, which he might deem unreasonable. The court relied on the Aurora case as an authority for the delegation doctrine, and both the majority and minority recognized that legislative power could not be delegated to the President. 
The doctrine has grown more liberal since the Field case-so liberal, indeed, that in recent decisions it has almost seemed to have ceased to exist. In many recent decisions, although the doctrine is invariably recognized, vague standards have been set which, in fact, seem to approach complete delegation of the legislative power, and yet the courts have found the acts involved to be constitutional. .x

The National Recovery Act, ${ }^{\mathrm{x}}$ involved in the Panama case, authorized the President "to prohibit the transportation in interstate and foreign commerce of petroleum and the products thereof, produced or withdrawn from storage in excess of the amount permitted to be produced or withdrawn from storage by any State law or valid regulation or order prescribed thereunder." The statute contains criminal provisions for its enforcement, and there is no standard set in section 9 (c) by which the President is to act; but section I of title $I^{I^{3}}$ was intended to be a declaration of policy setting a standard for the entire act. President Roosevelt put the section in question in operation by means of a series of executive orders. ${ }^{\mathrm{I}}$ The Panama suit was brought by oil refiners and producers to retrain federal officials from enforcing regulations ${ }^{\mathrm{IS}}$ issued under authority

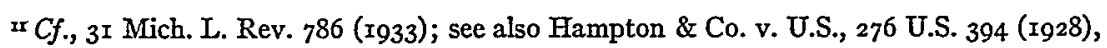
where the President was given power to equalize American and foreign costs of production by raising or lowering tariff schedules not more than $50 \%$; Fed. Radio Comm. v. Nelson Bros. Bond and Mtg. Co., 289 U.S. 266 (I933), in which the Federal Radio Commission was empowered by Congress to assign wave lengths as "public convenience, interest, or necessity requires"; New York Central Securities Corp. v. U.S., 287 U.S. I2 (I932), giving power to the Interstate Commerce Commission to control acquisition of one carrier by another, when it believes such acquisition will be "in the public interest." See also U.S. v. Grimaud, infra note Ig.

is Section 9 (c) of title I of the National Recovery Act, 48 Stat. I95 (r933), I5 U.S.C.A. $\S 709$ (c) (r934).

${ }_{23}$ "A national emergency productive of widespread unemployment and disorganization of industry, which burdens interstate and foreign commerce, affects the public welfare, and undermines the standards of living of the American people, is hereby declared to exist. It is hereby declared to be the policy of Congress to remove obstructions to the free flow of interstate and foreign commerce which tend to diminish the amount thereof; and to provide for the general welfare by promoting the organization of industry for the purpose of co-operative action among the trade groups, to induce and maintain united action of labor and management under adequate governmental sanctions and supervision, to eliminate unfair competitive practices, to promote the fullest possible utilization of the present productive capacity of industries, to avoid undue restriction of production (except as may be temporarily required), to increase the consumption of industrial and agricultural products by increasing purchasing power, to reduce and relieve unemployment, to improve standards of labor, and otherwise to rehabilitate industry and to conserve natural resources."

${ }_{14}$ Executive Orders no. 6199, July II, I933; no. 6204, July I4, I933; no. 6256, Aug. I9, I933 (which was eliminated on Sept. 13, 1933, but reinstated on Sept. 25, 1934).

${ }_{55}$ Dept. of Interior Reg. IV, V, and VII, July 15, r933, as amended July 25 and Aug. 21, I933. 
of section 9 (c). The Supreme Court ${ }^{16}$ upheld the plaintiff's contentions, holding that the delegation of power to the President was unconstitutional, since no standard had been set under which he was to act, and that section I was merely an introduction, "leaving the legislative policy as to particular subjects to be declared and defined, if at all, by the subsequent sections."17

This holding is noteworthy when considered in the light of the many liberal holdings in this field of the law, ${ }^{18}$ and particularly so when compared to the decision in the Grimaud case. ${ }^{19}$ In the past, necessity for prompt action and the handling of details has apparently been reason enough for the court to feel that these broad delegations should be upheld..$^{20}$ In times of depression so great that Congress feels it necessary to pass emergency legislation, it seems almost patent that such necessity exists, in spite of the view taken by the Supreme Court. The standard set in section $I$ is supplemented by standards in other sections ${ }^{2 x}$ applicable to codes of fair competition; and thus the present decision affects only the peculiar and limited operation of section 9 (c). Nevertheless, the court might have sustained the delegations as an extraordinary measure made necessary by the existence of an emergency. ${ }^{22}$ One authority ${ }^{23}$ suggests that the existence of an emergency might well make broader delegations valid because of the practical necessities of the case, citing the New York Fuel case. ${ }^{24}$

It might be well to point out that on February 22, last, Congress replaced the void section 9 (c) with an act more drastic in nature than the former one. ${ }^{25}$ The

${ }^{16} 55$ Sup. Ct. 24 I (1935).

17 Id., 247.

${ }^{18}$ Supra note II.

x9 U.S. v. Grimaud, 220 U.S. 506 (IgII). In this case Congress gave to the Secretary of Agriculture broad powers in making rules and regulations governing the use and occupancy of national forest reservations and providing that a violation would be a penal offense. In other words, "preservation of forests," a policy declaration, was deemed a sufficient standard. The court at page $5^{1} 6$, said the rules "are not of legislative character in the highest sense of the term."

${ }^{20} 48$ Harv. L. Rev. 798, 8or (I935). See also, for discussion of wartime power, Berdahl, War Powers of the Executive in the United States (I920), and for the powers delegated under the Transportation Act of rg2o, see Sharfman, The Interstate Commerce Commission (r93r), 177. In this connection see also New York Securities Co. v. U.S., 287 U.S. I2 (r932). For a striking exercise of the Interstate Commerce Commission's power, over railroad leases, see Nickel Plate Unification, I05 I.C.C. 425 (1926).

2x Particularly sections 7 (a) and 3.

22 The Supreme Court has not yet found itself ready to admit that an emergency national in scope exists, although in Atchison, Topeka and Santa Fe Ry. Co. v. U.S., 284 U.S. 248, 260 (1932), the court took judicial notice of the existence of a "depression."

23 Wickersham, Delegation of Power to Legislate, Ir Va. L. Rev. 183, I9r (1925).

24 People v. Moynihan, I2I Misc. 34, 200 N.Y.S. 434 (I923). At page 39 the court said, "In the emergency existing the legislature has enacted and from the necessities of the case it was compelled to leave to executive officials the enforcement of rules and orders to bring about the desired results."

${ }^{25}$ Pub. Law No. 14, 74th Congress, discussed in 2 U.S. Law Week, Feb. 26, 1935, at page 566. 
new act is a direct prohibition by Congress on interstate transport of oil produced in excess of state quotas. There is no delegation involved in the new act, although a newly established Federal Tender Board is entitled to require information under oath. Moreover, under the new act, contrabrand oil is forfeited. Current discussion is of course active with respect to oil control measures on the part of oil producing states and the federal government.

Although the immediate damage caused by the decision of the Panama case is repaired, the decision still remains important in future cases involving the doctrine of delegation of powers. 